\title{
Targeting PPAR $\gamma$ Receptor Using New Phosphazene Derivative Containing Thiazolidinedione: Design, Synthesis, and Glucose Uptake
}

\author{
Shaikha S. Al Neyadi', Abdu Adem², Naheed Amir², Ibrahim M. Abdou1* \\ ${ }^{1}$ Department of Chemistry, College of Science, UAE University, Al-Ain, UAE \\ ${ }^{2}$ Department of Pharmacology, College of Health and Science, UAE University, Al-Ain, UAE \\ Email: *shaikha.alneyadi@uaeu.ac.ae
}

How to cite this paper: Al Neyadi, S.S., Adem, A., Amir, N. and Abdou, I.M. (2020) Targeting PPAR $\gamma$ Receptor Using New Phosphazene Derivative Containing Thiazolidinedione: Design, Synthesis, and Glucose Uptake. Open Journal of Medicinal Chemistry, 10, 35-45.

https://doi.org/10.4236/ojmc.2020.102003

Received: March 14, 2020

Accepted: April 21, 2020

Published: April 24, 2020

Copyright $\odot 2020$ by author(s) and Scientific Research Publishing Inc. This work is licensed under the Creative Commons Attribution International License (CC BY 4.0).

http://creativecommons.org/licenses/by/4.0/

\begin{abstract}
The peroxisome proliferator activator receptor- $\gamma$ (PPAR- $\gamma$ ) remained the most effective target for management of diabetes mellitus. The present work endeavors rational designing new PPAR- $\gamma$ agonist bearing cyclotriphosphazene and thiazolidine-2,4-dione scaffolds. Thiazolidinedione (TZD) derivatives are the novel class of oral antidiabetic drugs which are selective agonist for the nuclear PPAR $\gamma$ that enhances the transcription of several insulin responsive genes but TZDs are known to cause weight gain, hepatotoxicity and fluid retention. So, cyclotriphosphazene containing thiazolidine-2,4-dione was designed, synthesized as $\operatorname{PPAR} \gamma$ agonist. The in-vitro antidiabetic activity showed that compound $\mathbf{8}$ has similar activity and exhibited higher glucose uptake in comparison to pioglitazone as reference drugs. This research opened new avenues for smart designing of molecules with high efficiency towards the management of hyperglycemia.
\end{abstract}

\section{Keywords}

Type 2 Diabetes, PPARs, TZD Compound, Cyclotriphosphazene

\section{Introduction}

Diabetes mellitus is a heterogenous group of disorder, characterized by a state of chronic hyperglycemia, resulting from a variety of etiologies either environmental and genetics, acting jointly [1]. Typically, diabetes is a long term metabolic disorder with a number of complications including cardiovascular, renal, neurological, ocular and other such inter-related problems. Diabetes mellitus (DM) 
is one of the major health problems in the world today. The incidence of the disease currently is estimated to reach 300 million by the year 2025. Most cases will be of Type 2 diabetes mellitus, which strongly linked with a sedentary life style and obesity. Recently, chemistry of 2,4-thiazolidinediones (TZDs) has attracted attention as they have been found to exhibit several biological activities, such as ntihyperglycemic, anti-inflammatory, antimalarial, antioxidant, antitumor, cytotoxic, antimicrobial, and antiproliferative. Thiazolidinediones (TZDs), which are known to sensitize tissues to insulin, have been developed and clinically used as antidiabetic agents. They have been shown to reduce plasma glucose, lipid, and insulin levels, and used for the treatment of type 2 diabetes [2]. As agonists of nuclear receptor peroxisome proliferator-activated receptor gamma (PPAR- $\gamma$ ), thiazolidinediones (TZD) reduce insulin resistance in the liver and peripheral tissues; increase the intake of insulin-dependent glucose and decrease withdrawal of glucose from the liver [3]. Many drugs have been approved from this class for the treatment of diabetes like Rosiglitazone, Pioglitazone, Ciglitazone and many more. Though the marketed drugs show additive effect with other antihyperglycemic agents, they are also prone to show toxicity. For example, Rosiglitazone shows hepatotoxicity [4].

Phosphazenes are class compounds with interesting properties. They showed a number of characteristics such as biomedical properties and applications due to their strong antitumor activity [5]. Their antimicrobial and biological activities on bacterial and yeast cells have been studied [6]. A variety of substitution reactions of the reactive $\mathrm{P}-\mathrm{Cl}$ bonds provide a wide range of cyclophosphazene derivatives, which have diverse applications [7]. These derivatives are usually synthesized by nucleophilic substitution reactions using alcohol, phenol, amines, Grignard reagents and thiols [8]. Their physical and chemical properties can be tailored by appropriate substituents on the phosphorus atoms.

Hence, there is a need for the development of newer and safer drugs from this class. There is still an urgent need for novel anti-diabetic agents that should have a similar degree of efficacy with a potential to reduce long-term complications. In our efforts to develop the biological profile of these analogues, we have reported an efficient synthesis and screening of new thiazolidinedione derivative as potential antidiabetic drugs. Inspired by the diverse biological properties of thiazolidinedione moiety and cyclotriphosphazene, in the present study, an attempt has been made to synthesize title compound by employing hybridization approach with the hope that the resulting new molecules will have anti-diabetic activity. The structures of the synthesized compounds were assigned based on elemental analysis, IR, ${ }^{1} \mathrm{H},{ }^{13} \mathrm{C}$ and ${ }^{31} \mathrm{P}$ NMR spectroscopy. The compound was also screened for their in-vitro antidiabetic activity.

\section{Material and Methods}

\subsection{Chemistry}

All reagents and chemicals were purchased from Sigma-Aldrich and used with- 
out further purification. Thin-layer chromatography (TLC) was performed on silica gel glass plates (Silica gel, $60 \mathrm{~F}_{254}$, Fluka) and the spots were visualized under a UV lamp. Column chromatography was performed on a Kieselgel S (silica gel S, $0.063-0.1 \mathrm{~mm}$ ). The melting points were recorded on a Gallenkamp apparatus and were uncorrected. Infrared spectra were measured using $\mathrm{KBr}$ pellets on a Thermo Nicolet model 470 FT-IR spectrophotometer. ${ }^{1} \mathrm{H}-\mathrm{NMR}$ spectra were recorded on $400 \mathrm{MHz}$ Varian instruments using DMSO- $d_{6}$ and $\mathrm{CDCl}_{3}$ solutions and tetramethylsilane (TMS) as an internal reference. The elemental analysis was performed on Elemental Analysis performed on Leco Model CHN600 elemental analyzer. Microwave synthetic protocol done using CEM Microwave system.

\subsubsection{Synthesis of 2,2-Dichloro-4,4,6,6-Bis [Spiro (2',2"-Dioxy-1',1"- Biphenylyl]Cyclotriphosphazene (3)}

$\mathrm{N}_{3} \mathrm{P}_{3} \mathrm{Cl}_{6}(2 \mathrm{~g}, 5.75 \mathrm{mmol})$, bip-henyl-2,2'-diol $(2.14 \mathrm{~g}, 11.51 \mathrm{mmol})$ and $\mathrm{K}_{2} \mathrm{CO}_{3}$ (3.98 g, $28.77 \mathrm{mmol}$ ) were mixed in $20 \mathrm{ml}$ acetone at $0^{\circ} \mathrm{C}$. The reaction mixture was stirred at room temperature for 24 hours and when the reaction was complete the solvent was removed in vacuo. The product was extracted by washing with $20 \mathrm{ml}$ of DCM three times. The solvent was then removed under vacuum to produce a white powder. Yield $88 \% ; \mathrm{mp}=274^{\circ} \mathrm{C} ;{ }^{1} \mathrm{H} \mathrm{NMR}\left(\mathrm{CDCl}_{3}, 400 \mathrm{MHz}\right): \delta$ ppm $7.53\left(4 \mathrm{H}, \mathrm{d}, J=7.5, \mathrm{H}_{5}\right), 7.63\left(4 \mathrm{H}, \mathrm{t}, J=7.6, \mathrm{H}_{3}\right), 7.33\left(8 \mathrm{H}, \mathrm{m}, \mathrm{H}_{2}, \mathrm{H}_{4}\right),{ }^{13} \mathrm{C}$ NMR $\left(\mathrm{CDCl}_{3}, 100 \mathrm{MHz}\right): \delta \mathrm{ppm} 147.8\left(\mathrm{~d}, J_{P O O} 8.9 \mathrm{~Hz}, \mathrm{C}_{1}\right), 130.0\left(\mathrm{C}_{5}\right), 129.8$ $\left(\mathrm{C}_{3}\right), 128.8\left(\mathrm{C}_{6}\right), 126.6\left(\mathrm{C}_{4}\right), 122.0\left(\mathrm{C}_{2}\right)$.

\subsubsection{2,2-Bis(4-Formylphenoxy)-4,4,6,6-Bis[Spiro(2',2"-Dioxy-1',1"'- Biphenylyl]Cyclotriphosphazene (5)}

To a mixture of $3(1 \mathrm{mmol})$ and 4-hydroxybezaldehyde $(2 \mathrm{mmol})$ in dry acetonitrile, kept at $0^{\circ} \mathrm{C}, \mathrm{K}_{2} \mathrm{CO}_{3}(5 \mathrm{mmol})$ was added. The reaction was stirred on the ice-bath for 5 minutes then the vessel was closed immediately and was subjected to microwave irradiation at $140^{\circ} \mathrm{C}$ for about $30 \mathrm{~min}$. After cooling to r.t, $20 \mathrm{~mL}$ of ethyl acetate was added and solution was neutralized with drop wise addition of $\sim 6 \mathrm{M} \mathrm{HCl}(\mathrm{pH}=7-7.5)$, washed with a saturated $\mathrm{NaHCO}_{3}$ and $\mathrm{NaCl}$ solution $(1: 3,1 \times 50 \mathrm{~mL})$. Aqueous layer was rewashed with ethyl acetate $(2 \times 25 \mathrm{~mL})$ and the combined organic layer was dried. The product was purified by silica gel column chromatography with hexanes/dichloromethane/ethylacetate as an eluent to give 5 . This compound was white powder, yield $89 \%$; $\mathrm{mp}: 224^{\circ} \mathrm{C}$; ${ }^{1} \mathrm{H}$ NMR (DMSO, $\left.400 \mathrm{MHz}\right): \delta \mathrm{ppm} 7.14(4 \mathrm{H}, \mathrm{d}, J=7.80 \mathrm{~Hz}), 7.38-7.65(12 \mathrm{H}$, m), $7.68(4 \mathrm{H}, \mathrm{t}), 8.13(4 \mathrm{H}, \mathrm{d}, 8.2 \mathrm{~Hz}), 10.10(2 \mathrm{H}, \mathrm{s}, \mathrm{CHO}) ;{ }^{13} \mathrm{C}$ NMR (DMSO, 100 $\mathrm{MHz}): \delta \mathrm{ppm} 192.3(\mathrm{CHO}), 154.6\left(\mathrm{C}_{10}\right), 147.6\left(\mathrm{C}_{1}\right), 134.5\left(\mathrm{C}_{8}\right), 132.4\left(\mathrm{C}_{5}\right), 130.8$ $\left(\mathrm{C}_{7}\right), 130.5\left(\mathrm{C}_{3}\right), 128.3\left(\mathrm{C}_{6}\right), 127.3\left(\mathrm{C}_{4}\right), 122.1\left(\mathrm{C}_{2}\right), 122.1\left(\mathrm{C}_{9}\right)$.

\subsubsection{Synthesis of Phosphazene-Thiazolidinedione (8)}

A mixture of $N$-methylthiourea $6(3.0 \mathrm{mmol}, 0.27 \mathrm{~g})$, chloroacetic acid 7 (3.6 $\mathrm{mmol}, 0.2 \mathrm{ml})$ and aldehyde $5(3.0 \mathrm{mmol}, 0.74 \mathrm{~g})$ was heated under microwave irradiation at $90^{\circ} \mathrm{C}-110^{\circ} \mathrm{C}$ for $10-20 \mathrm{~min}$. After cooling to room temperature, 
the reaction mixture was extracted with $\mathrm{CH}_{2} \mathrm{Cl}_{2}$. The organic layer washed with aquous $\mathrm{NaHCO}_{3}$, water and dried over anhydrous $\mathrm{Na}_{2} \mathrm{SO}_{4}$. The solvent was removed under vacuum and the residue was recrystallized from $\mathrm{EtOH} /$ water to give 7 as pale yellow powder; yield $90 \%$; mp $213^{\circ} \mathrm{C}$; IR $\left(\mathrm{KBr}, \mathrm{cm}^{-1}\right): 3423(\mathrm{NH})$, $3064\left(\mathrm{C}-\mathrm{H}\right.$, aromatic), $1688(\mathrm{C}=\mathrm{O}), 1503(\mathrm{C}=\mathrm{N}) ;{ }^{1} \mathrm{H}-\mathrm{NMR}$ [DMSO- $d_{\odot} 400$ $\mathrm{MHz}$ : $(\delta, \mathrm{ppm}) 3.07\left(\mathrm{~s}, 6 \mathrm{H}, \mathrm{CH}_{3}\right), 5.73$ (brs, $2 \mathrm{H}, \mathrm{NH}$, exchanges with $\left.\mathrm{D}_{2} \mathrm{O}\right), 7.14$ $7.16(4 \mathrm{H}, \mathrm{d}, \mathrm{J}=7.80 \mathrm{~Hz}), 7.39-7.53(\mathrm{~m}, 12 \mathrm{H}$, aromatic $\mathrm{H}), 7.64(\mathrm{~m}, 4 \mathrm{H}$, aromatic H), 7.79 - $7.81(4 \mathrm{H}, \mathrm{d}, \mathrm{J}=8.2 \mathrm{~Hz}), 7.95$ (s, 2H, methylene); ${ }^{13} \mathrm{C}-\mathrm{NMR}$ [DMSO- $\left.d_{6}, 100 \mathrm{MHz}\right]:(\delta, \mathrm{ppm}) 28.3\left(\mathrm{CH}_{3}\right), 122.1,122.3,127.2,128.2,130.4$, 130.8, 131.2, 131.8, 132.6, (aromatic C), 147.48 (methylene C), 151.42 (C-O), $151.48(\mathrm{C}-\mathrm{O}), 166.23(\mathrm{C}=\mathrm{N}), 167.75(\mathrm{C}=\mathrm{O}) ;{ }^{31} \mathrm{P}$ NMR: $9.44(\mathrm{t}), 25.33(\mathrm{~d})$; Anal. Calcd for $\mathrm{C}_{46} \mathrm{H}_{34} \mathrm{~N}_{7} \mathrm{O}_{8} \mathrm{P}_{3} \mathrm{~S}_{2}$ : C, 56.97; H, 3.53; N, 10.11; S, 6.61; Found: C, 57.42; H, $3.61 ; \mathrm{N}, 10.40 ; \mathrm{S}, 6.89$.

\subsection{Anti-Diabetic Activity}

\subsubsection{In-Vitro Testing}

\section{1) Cell culture}

$\beta$ TC6 cells, a mouse immortalized insulin-secreting pancreatic beta cell line (T-SV40), were grown in DMEM culture medium containing $25.0 \mathrm{mM}$ glucose, $1.0 \mathrm{mM}$ sodium pyruvate, $4.0 \mathrm{mM}$ L-glutamine, $44.0 \mathrm{mM}$ sodium bicarbonate, $15.0 \%(\mathrm{v} / \mathrm{v}) \mathrm{FBS}$, and $50.0 \mu \mathrm{g} / \mathrm{ml}$ gentamicin in a $5.0 \% \mathrm{CO}_{2}$ incubator at $37^{\circ} \mathrm{C}$. The medium was changed every $48 \mathrm{hrs}$ with fresh culture medium and cells sub-cultured as necessary to prevent over-confluence. Cells were passaged by treatment with $0.25 \%$ trypsin and $0.91 \mathrm{mM}$ EDTA at passages 6 - 8 .

\section{2) Insulin secretion assay}

$\beta$ TC6 cells $\left(0.1 \times 10^{6}\right.$ cells $\left./ \mathrm{ml}\right)$ was cultured in a 24 -well plate for $48 \mathrm{hr}$ in $5 \%$ $\mathrm{CO}_{2}$ incubator at $37^{\circ} \mathrm{C}$. The cells were then preincubated for 30 minutes in modified Krebs/Ringer buffer (KRB) (118.5 mM NaCl, $25 \mathrm{mM} \mathrm{NaHCO}_{3}, 4.74 \mathrm{mM}$ $\mathrm{KCl}, 1.19 \mathrm{mM} \mathrm{MgSO}_{4}, 2.54 \mathrm{mM} \mathrm{CaCl}_{2}, 10 \mathrm{mM}$ HEPES, $1.19 \mathrm{mM} \mathrm{KH}_{2} \mathrm{PO}_{4}, 0.1 \%$ $\mathrm{BSA}, \mathrm{pH}$ 7.4) in the $\mathrm{CO}_{2}$ incubator. Resultant cells were washed and incubated for another $30 \mathrm{~min}$ with fresh buffer. Solutions of compound $8\left(10^{-6}-10^{-12} \mathrm{M}\right)$ were prepared by diluting the stock standard solutions by KRB. Solutions having $0.000004 \%$ DMSO were obtained. $250 \mu$ of the different concentrations were added to the cells and incubated in a $5 \% \mathrm{CO}_{2}$ incubator at $37^{\circ} \mathrm{C}$ for $120 \mathrm{~min}$ in the absence and presence of $2.80 \mathrm{mM}$ glucose solution. Total reaction volume was $1 \mathrm{ml}$ for each experiment. To maintain total volume of $1 \mathrm{ml}$, either $750 \mu \mathrm{l}$ or $500 \mu \mathrm{KRB}$ was added first followed by $250 \mu \mathrm{l}$ of 4 time's concentrated dose of compound and glucose (Basal experiment: $750 \mu \mathrm{KRB}+4 \mathrm{X} 250 \mu \mathrm{l}$ test drug. Glucose stimulated experiment: $500 \mu \mathrm{KRB}+4 \mathrm{X} 250 \mu \mathrm{l}$ glucose $2.8 \mathrm{mM}+4 \mathrm{X}$ $250 \mu \mathrm{l}$ test drug). After incubation, the supernatant layers were collected and subjected to sandwich ELISA using a high range insulin assay kit according to the manufacturer's instruction. As per instructions from the manufacturer of the kit, $10 \mu \mathrm{l}$ samples were incubated with enzyme conjugate solutions on shaker plates for $2.0 \mathrm{hrs}$ at room temperature. The plates were washed, TMB was added 
for $15 \mathrm{~min}$ and the reaction was stopped. The color intensity of solutions was read at $450 \mathrm{~nm}$ with a Tecan microplate reader. The sensitivity of insulin ELISA was $216 p \mathrm{~mol} / \mathrm{L}$. The average intra and inter assay coefficients of variation were $3.37 \%$ and $2.29 \%$, respectively. The levels of insulin were expressed as $p \mathrm{~mol} / \mathrm{L}$.

\subsubsection{Glucose Uptake Cell-Based Assay}

Cayman's Glucose Uptake Cell-based Assay Kit was used as a tool for studying modulators of cellular glucose uptake. The kit employs 2-[ $N$-(7-nitrobenz-2oxa-1,3-diaxol-4-yl)amino]-2-deoxyglucose (2-NBDG), a fluorescently-labeled deoxyglucose analog, as a probe for the detection of glucose taken up by cultured cells. $\beta$ TC6 Cells at $5 \times 10^{4}$ cells $/ \mathrm{mL}$ was seeded onto a 96-well clear flat bottom black plate and allowed to adhere overnight at $37^{\circ} \mathrm{C}, 5 \% \mathrm{CO}_{2}$ in tissue culture media (DMEM containing $25 \mathrm{mM}$ glucose, $1 \mathrm{mM}$ Sodium Pyruvate, $4 \mathrm{mM}$ L-Glutamine, $44.05 \mathrm{mM}$ Sodium Bicarbonate $\left(\mathrm{NaHCO}_{3}\right), 15 \%$ (v/v) FBS, and 50 $\mu \mathrm{g} / \mathrm{ml}$ Gentamicin). The complete medium was then removed and the cells were washed with Krebs/Ringer buffer (KRB) (118.5 mM NaCl, $25 \mathrm{mM} \mathrm{NaHCO}_{3}, 4.74$

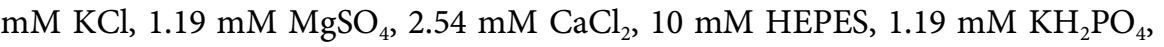
$0.1 \% \mathrm{BSA}, \mathrm{pH} 7.4$ ). Conditioning of the cells proceeded at $37^{\circ} \mathrm{C}, 5 \% \mathrm{CO}_{2}$ for 30 mins, two times. The conditioning buffer was then removed and replaced with $450 \mu \mathrm{M} 2$-NBDG along with $10 \mu \mathrm{M}$ either test compound or $10 \mu \mathrm{M}$ reference drug in KRB. The cells were then incubated further at $37^{\circ} \mathrm{C}, 5 \% \mathrm{CO}_{2}$ for $10 \mathrm{mins}$ to allow them to endocytose the glucose analog. At the end of the treatment, plate was centrifuged for $5 \mathrm{~min}$ at $400 \times \mathrm{g}$ at room temperature. The 2-NBDG in basal medium was then removed and the cells were washed with $200 \mu \mathrm{l}$ Cell-Based Assay Buffer. Plate was centrifuge for $5 \mathrm{~min}$ at $400 \times \mathrm{g}$ at room temperature. $100 \mu \mathrm{l}$ of Cell-Based Assay Buffer was added to each well after the aspiration of the supernatant. The amount of 2-NBDG taken up by cells was measured immediately at excitation and emission wavelengths of $485 \mathrm{~nm}$ and $535 \mathrm{~nm}$ respectively in TECAN infinite M200 micro plate reader.

\subsubsection{Statistical Analysis}

Experimental results were expressed as mean \pm SEM and statistically assessed by SPSS-20. The difference between test animals and control was evaluated using the Student t-test.

\section{Results and Discussion}

\subsection{Chemistry}

The synthesis to produce the dioxybiphenyl derivative 3 via the reaction depicted in Figure 1. Starting from hexachlorocyclotriphosphazene 1, two equivalents of bip-henyl-2,2'-diol 2 were added to four equivalents of potassium carbonate. In this case, only two equivalents of the reagent are needed as one bip-henyl-2,2'-diol is capable of bonding to one phosphorus atom through the two deprotonated oxygen molecules. Two phosphorus atoms are then substituted with this bulky group. This reaction was performed in acetone as the reaction has been proven 


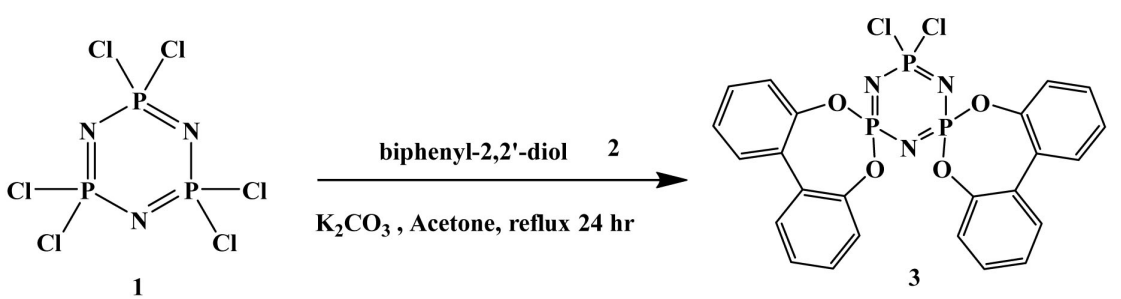

Figure 1. Synthesis of compound 3.

to occur faster in acetone than in THF [9]. It was also not necessary to reflux the first step in this reaction as this bifunctional nucleophile promotes the replacement of the chlorine atoms. In fact, the trimer and biphenol were added to acetone that was cooled in an ice bath. This is presumably done to prevent the reaction from taking place too fast and forming trimer that is triply substituted with bip-henyl-2,2'-diol [9]. When the first nucleophilic oxygen reacts with the phosphorus atom, it activates the phosphorus atom for further substitution (geminal substitution) [10]. The neighbouring oxygen is the next-closest nucleophile and substitution of the second chlorine atom occurs. Crosslinking of trimer molecules does not occur because the closest reactive site is on the same molecule [9]. The reaction mixture was stirred at room temperature for 24 hours under an atmosphere of dry nitrogen because bip-henyl-2,2'-diol is air sensitive. The solvent was then removed under vacuum and the product extracted with DCM. More than one product can possibly form during the reaction, but the main product is isolated via extraction and recrystallisation as the solubility of the doubly and triply substituted derivatives differs in different solvents.

The reaction depicted in Figure 2 was carried out by microwave in which 2 equiv. of 4-hydroxybenzaldehyde reacted with 3 in the presence of $\mathrm{K}_{2} \mathrm{CO}_{3}$ in acetonitrile for $30 \mathrm{~min}$ at $140^{\circ} \mathrm{C}$ gave 2,2-bis(4-formylphenoxy)-4,4,6,6-bis [spiro(2',2"dioxy$1^{\prime}, 1^{\prime \prime}$-biphenylyl)]cyclotriphosphazene $\mathbf{5}$. It is necessary to increase temperature in this step as the groups on the cyclotriphosphazene ring are quite bulky, causing steric hindrance which would mean that the reaction will need more energy to take place. It was not necessary to do this reaction under inert conditions. The work-up for the second step is similar to the first step. The solvent was removed under vacuum and the product extracted with dichloromethane (DCM). The DCM was then removed in vacuo.

The new phosphazene derivative containing a thiazolidine-2,4-dione 8 was synthesized from the reaction of 5 with $N$-methyl thiourea and monochloroacetic acid under microwave-irradiation for 15 min succeeded to afford the desired product 8 in $90 \%$ yield. Compound 8 was characterized by elemental analysis, FT-IR, ${ }^{1} \mathrm{H},{ }^{13} \mathrm{C},{ }^{31} \mathrm{P}$ NMR techniques (Figure 3 ).

The structure of the obtained compound was established based on their elemental analysis together with their compatible spectra data. The IR spectra of compound showed characteristic absorption bands at $3423 \mathrm{~cm}^{-1}$ and $1688 \mathrm{~cm}^{-1}$ corresponding to the $-\mathrm{NH}$ and $\mathrm{C}=\mathrm{O}$ groups in the obtained structure. Another band at $1503 \mathrm{~cm}^{-1}$ attributed to $\mathrm{C}=\mathrm{N}$ group. In addition, the ${ }^{1} \mathrm{H}-\mathrm{NMR}$ spectrum 


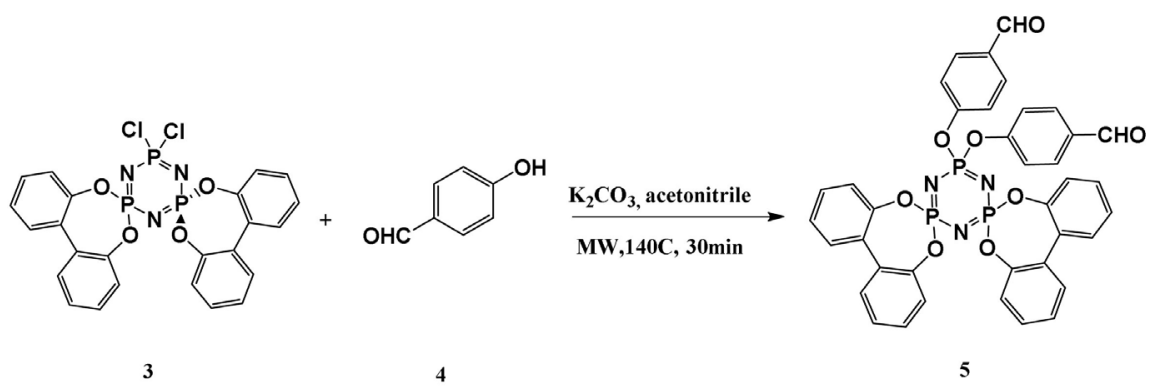

Figure 2. Synthesis of compound 5.
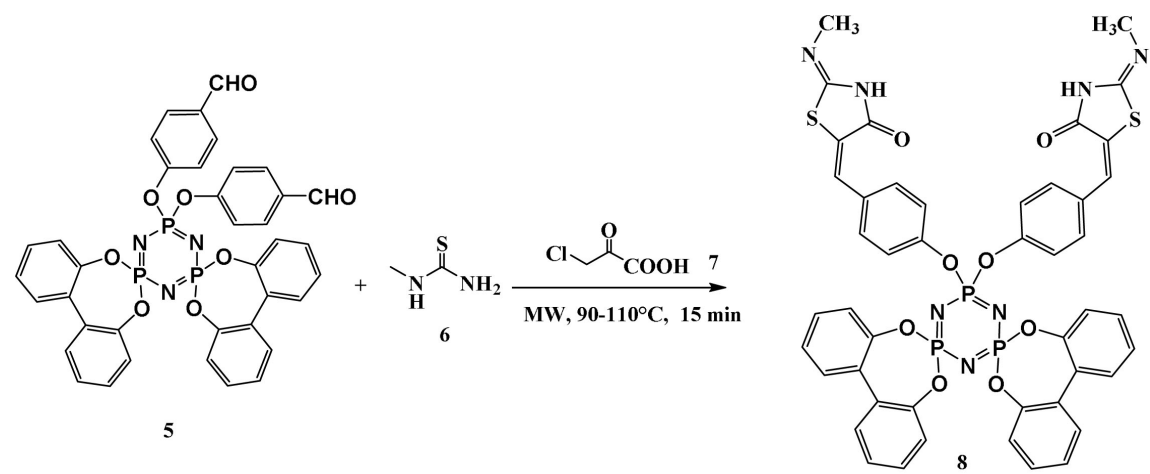

Figure 3. Synthesis of compound 8.

showed the absence of aldehyde protons at $\delta=10.01 \mathrm{ppm}$ confirmed the formation of the product. ${ }^{1} \mathrm{H}-\mathrm{NMR}$ spectrum indicated the presence of amino group in the region of $\delta=5.73 \mathrm{ppm}$ accounting to two protons indicates the formation of target compound which discharged with $\mathrm{D}_{2} \mathrm{O}$. Besides, the appearance of singlet signal at $\delta=7.95 \mathrm{ppm}$ for the methine-group hydrogen indication formation of $Z$-isomer which is more downfield compared to $E$-isomer. The ${ }^{13} \mathrm{C}-\mathrm{NMR}$ spectrum showed signal at $\delta=147.5$ assigned for the methane carbon. The $(\mathrm{C}=\mathrm{O})$ carbon of thiazoldione resonate at $\delta=167.8 \mathrm{ppm}$. The elemental analysis $(\mathrm{C}, \mathrm{N}$ and $\mathrm{H}$ ) found for all the condensed products was in close agreement with the calculated values (Figure 4). The ${ }^{31} \mathrm{P}$ NMR spectrum of 8 two signals were observed as one doublet and one triplet, which indicates that the two phosphorus atoms attached to the dioxybiphenyl ring are not magnetically equal. This non-equivalence of the two phosphorus atoms maybe due to the difference in the angle of twist of the two phenyl groups of the biphenyl moieties and their twistss in a different direction. The reason for this reversal twist/distortion could be due to the advantageous thermodynamically stable seven-membered dioxybiphenyl ring conformation by imparting reduced 6,6 hydrogen-hydrogen contacts without broadening the O-P-O angle.

\subsection{Anti-Diabetic Activity}

Peroxisome proliferator-activated receptors (PPARs) are known transcription factors that directly control the expression of genes involved in lipid and glucose metabolism [11]. The mechanism of PPARs has been described [12]. Among the 


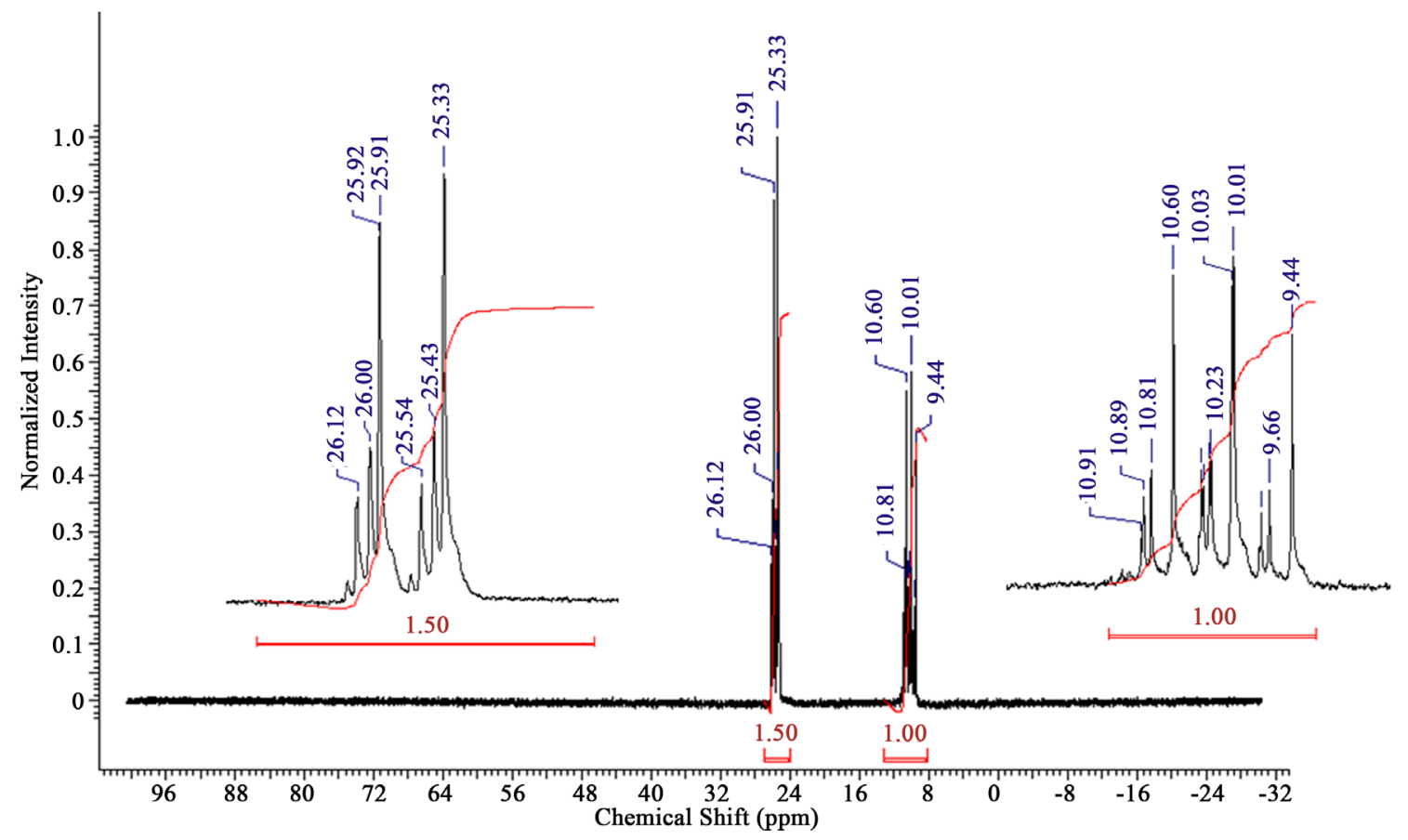

Figure 4. The ${ }^{31} \mathrm{P}$ NMR spectrum of compound 8 .

three isotypes of PPARs (PPAR $\alpha, \operatorname{PAAR} \beta$ and PPAR $\gamma$ ), PPAR $\gamma$ is the most studied for drug discovery. PPAR $\gamma$ was not only identified as a key regulator of adipogenesis, but it also plays an important role in type 2 diabetes, cellular differentiation, insulin sensitization, atherosclerosis and cancer [13]. A class of highaffinity $\operatorname{PPAR} \gamma$ synthetic ligands includes the anti-diabetic thiazolidinedione (TZD) drugs, such as troglitazone, rosiglitazone, pioglitazone and ciglitazone [14]. Rosiglitazone and pioglitazone are currently marketed $\operatorname{PPAR} \gamma$ activators used for the treatment of type 2 diabetes to reduce hyperglycemia by promoting insulin action without additional insulin secretion [15]. TZD-type improves insulin resistance with side effects like weight gain, fluid retention and edema. In the present study, a novel and effective thiazolidinedione-2,4-dione derivative have been synthesized as potential antidiabetic drugs that may bind and activate $\operatorname{PPAR} \gamma$ and enhances insulin sensitivity. An in-vitro study showed that the new thiazolidinedione-2,4-dione derivative provides a new insight concerning their effect on PPAR $\gamma$.

\subsubsection{Effect of Compound 8 on Insulin Secretion from $\beta$ TC6 Cell Line}

Secretion of insulin by $\beta$ TC6 cells was measured using the high range insulin Sandwich ELISA kit. Figure 5(a) shows the effect of pioglitazone on insulin secretion in the presence and absence of $2.88 \mathrm{mM}$ glucose. As can be seen from Figure 5(a), pioglitazone does not show any effect on basal or glucose stimulated insulin secretion. The effects of compound 8 at $10^{-12}, 10^{-9}, 10^{-6} \mathrm{M}$ concentrations were investigated on insulin secretion in absence and presence of $2.8 \mathrm{mM}$ glucose from $\beta$ TC6 cells. Compound 8 did not show any effect on the secretion of insulin in the absence or presence of glucose (Figure 5(b)). 


\subsubsection{Glucose Uptake Assay}

The results of the in vitro glucose uptake study indicate that the compound $\mathbf{8}$ was found to exhibit remarkable potential to flush glucose into the mentioned cells as compared to standard reference Pioglitazone. Compound 8 happens to be a potent compound by enhancing the glucose uptake significantly $(\mathrm{P}<0.05)$ (Figure 6).

\section{Conclusion}

In this study, we report the synthesis of novel phosphazene derivatives containing Thiazolidinediones group using the reaction of 2,2-bis(4-formylphenoxy)4,4,6,6-bis[spiro(2',2"-dioxy-1',1"'-biphenylyl]cyclotriphosphazene with $N$-methyl thiourea and monochloroacetic acid under microwave-irradiation. All products were generally obtained in high yields $(88 \%-90 \%)$. The in-vitro antidiabetic activity showed that compound exhibited higher glucose uptake in comparison to pioglitazone as reference drugs. Thus, analogs of phosphazene derivatives of thiazolidinediones may be potential insulin sensitizers and may be developed further in the future in the management of diabetes. The study also provides directions in designing more potent, safe, selective and cost-effective molecule.

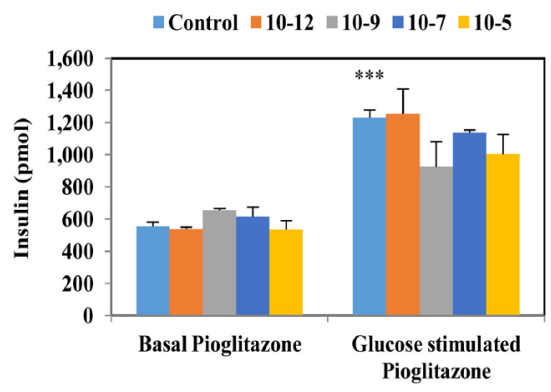

(a)

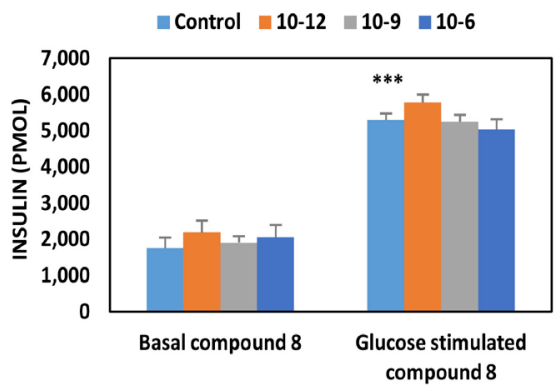

(b)

Figure 5. The effects of the Pioglitazone (a) and compound $8\left(10^{-12}-10^{-6} \mathrm{M}\right)(\mathrm{b})$ on insulin secretion in $\beta$ TC6 cells in the absence (basal) and in the presence of $2.8 \mathrm{mM}$ glucose concentration. Results are means of triplicates $\pm \mathrm{SEM} ;{ }^{\star} \mathrm{P}<0.05,{ }^{\star *} \mathrm{P}<0.01,{ }^{\star * \star} \mathrm{P}<0.001$ from relative basal control and $\#^{*} \mathrm{P}<0.05$, \#\# $\mathrm{P}<0.01$, \#\#\# $\mathrm{P}<0.001$ from glucose 2.8 mM.

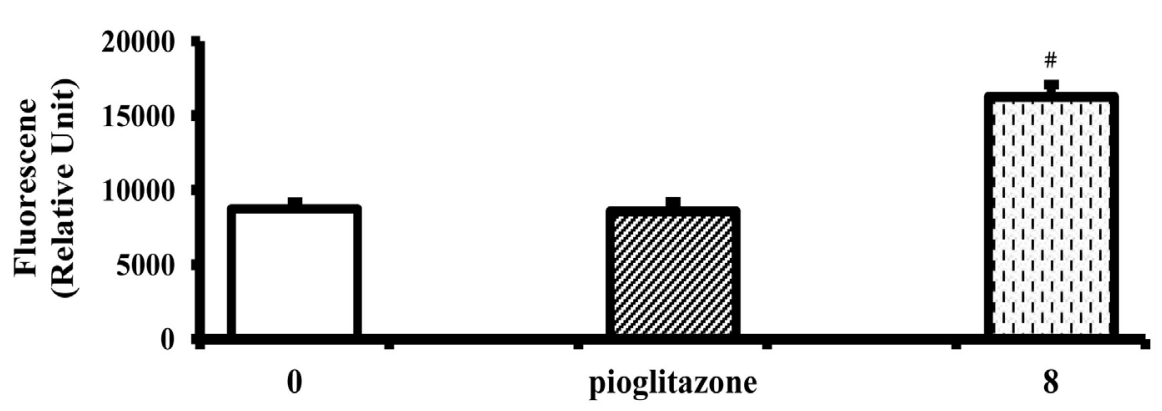

Figure 6. The effects of compound $8(10 \mu \mathrm{M})$ on glucose uptake from $\beta$ TC6 cells. Results are means of triplicates $\pm \mathrm{SEM}$; ${ }^{\star} \mathrm{P}<0.05$ vs. control (zero concentration); $\#^{\star} \mathrm{P}<0.05$ vs. reference drug (pioglitazone). 


\section{Acknowledgements}

The authors wish to acknowledge the significant financial support of UAE University, Research Affairs Sector (Grant no. 31S030-1156-02-02-10).

\section{Conflicts of Interest}

The authors declare no conflicts of interest regarding the publication of this paper.

\section{References}

[1] Musmade, D.S., et al. (2009) Synthesis and Biological Evaluation of Some 1,3,4Thiadiazoles. Journal of Chemical and Pharmaceutical Research, 1, 191-198.

[2] Day, C. (1999) Thiazolidinediones: A New Class of Antidiabetic Drugs. Diabetic Medicine, 16, 179-192. https://doi.org/10.1046/j.1464-5491.1999.00023.x

[3] Kim, H., Haluzik, M., Gavrilova, O., Yakar, S., Portas, J., Sun, H., Pajvani, U.B., Scherer, P.E. and LeRoith, D. (2004) Thiazolidinediones Improve Insulin Sensitivity in Adipose Tissue and Reduce the Hyperlipidemia without Affecting the Hyperglycaemia in a Transgenic Model of Type 2 Diabetes. Diabetologia, 47, 2215-2225. https://doi.org/10.1007/s00125-004-1581-6

[4] Kahn, S.E., Haffner, S.M., Heise, M.A., Herman, W.H., Holman, R.R., Jones, N.P., Kravitz, B.G., Lachin, J.M., O’Neill, M.C., Zinman, B., Viberti, G. and ADOPT Study Group (2006) Glycemic Durability of Rosiglitazone, Metformin, or Glyburide Monotherapy. The New England Journal of Medicine, 355, 2427-2443. https://doi.org/10.1056/NEJMoa066224

[5] Liu, Y. (2013) Relationship between Industrial Firms, High-Carbon and LowCarbon Energy: An Agent-Based Simulation Approach. Applied Mathematics and Computation, 219, 7472-7479. https://doi.org/10.1016/j.amc.2013.01.034

[6] Chen, K., et al. (2007) Molecular-Docking-Guided Design, Synthesis, and Biologic Evaluation of Radioiodinated Quinazolinone Prodrugs. Journal of Medicinal Chemistry, 50, 663-673. https://doi.org/10.1021/jm060944k

[7] Liu, X., et al. (2012) Substituent Exchange Reactions of Trimeric and Tetrameric Aryloxycyclophosphazenes with Sodium 2,2,2-Trifluoroethoxide. Dalton Transactions, 41, 2100-2109. https://doi.org/10.1039/C1DT11606A

[8] Siwy, M., et al. (2006) Synthesis and in Vitro Antileukemic Activity of Some New 1,3-(Oxytetraethylenoxy) Cyclotriphosphazene Derivatives. Journal of Medicinal Chemistry, 49, 806-810. https://doi.org/10.1021/jm0490078

[9] Carriedo, G.A., Fernández-Catuxo, L., García Alonso, F.J., Gómez-Elipe, P. and González, P.A. (1996) Preparation of a New Type of Phosphazene High Polymers Containing 2,2'-Dioxybiphenyl Groups. Macromolecules, 29, 5320-5325. https://doi.org/10.1021/ma951830d

[10] Greenwood, N.N. and Earnshaw, A. (1998) Chemistry of the Elements. 2nd Edition, Elsevier, Amsterdam.

[11] Hédou, D., et al. (2013) Novel Synthesis of Angular Thiazolo[5,4-f] and [4,5-h]quinazolines, Preparation of Their Linear Thiazolo[4,5-g] and [5,4-g]quinazoline Analogs. Tetrahedron, 69, 3182-3191. https://doi.org/10.1016/j.tet.2013.02.066

[12] Sánchez, A.I., et al. (2013) Synthesis and Evaluation of Quinazoline Derivatives as Phosphodiesterase 7 Inhibitors. Bioorganic \& Medicinal Chemistry, 21, 2370-2378. 
https://doi.org/10.1016/j.bmc.2013.01.067

[13] Walpole, C., et al. (2012) Diastereoselective Synthesis of Fluorinated Piperidine Quinazoline Spirocycles as iNOS Selective Inhibitors. Tetrahedron Letters, 53, 2942-2947. https://doi.org/10.1016/j.tetlet.2012.03.050

[14] Abbott, P.A., et al. (2002) Fused Mesoionic Heterocycles: Synthesis of [1,2,3]triazolo [1,5-a]quinoline, $[1,2,3]$ triazolo[1,5-a]quinazoline, [1,2,3]triazolo[1,5-a]quinoxaline and [1,2,3]triazolo[5,1-c] benzotriazine Derivatives. Tetrahedron, 58, 3185-3198. https://doi.org/10.1016/S0040-4020(02)00269-7

[15] Harayama, T., et al. (2004) Concise Synthesis of Quinazoline Alkaloids, Luotonins A and B, and Rutaecarpine. Tetrahedron, 60, 10645-10649.

https://doi.org/10.1016/j.tet.2004.09.016 